Journal of Applied Pharmaceutical Science Vol. 6 (01), pp. 118-124, January, 2016

Available online at http://www.japsonline.com

DOI: $10.7324 / \mathrm{JAPS} .2016 .600119$

ISSN 2231-3354 (cc) EY-NC-SA

\title{
Protective effect of phenolic extracts from two species of miracle berry leaves (Thaumatococcus daniellii and Megaphrynium macrostachyum) on some pro-oxidant induced oxidative stress in rat pancreas in vitro
}

\author{
Ganiyu Oboh ${ }^{1}$, Ayodele J. Akinyemi ${ }^{1,2^{*}}$, Idowu S. Oyeleye ${ }^{1}$, Kemi Williamsnelson ${ }^{1}$ \\ ${ }^{1}$ Department of Biochemistry, Federal University of Technology, Akure, Nigeria P.M.B., 704, Akure 340001, Nigeria. \\ ${ }^{2}$ Department of Biochemistry, Afe Babalola University, Ado-Ekiti, Nigeria P.M.B., 5454, Nigeria.
}

\section{ARTICLE INFO \\ Article history: \\ Received on: 09/09/2015 \\ Revised on: 22/10/2015 \\ Accepted on: 09/11/2015 \\ Available online: 26/01/2016}

Key words:

Thaumatococcus daniellii, Megaphrynium

macrostachyum, Oxidative

stress, Antioxidant.

\begin{abstract}
Traditionally, miracle berry leaves are mostly used as food wrappers in order to increase the shelf life of the food. Therefore, this study sought to investigate the antioxidative properties and protective effect of phenolic extracts from two species of miracle berry leaves namely; Thaumatococcus daniellii (Benn) Benth and Megaphrynium macrostachyum (Benth) Milne-Redh on some pro-oxidant induced oxidative stress in rat pancreas in vitro. The phenolic extract was prepared with $80 \%$ acetone $(\mathrm{v} / \mathrm{v})$; thereafter, ability of the extracts to inhibit some prooxidants $\left(\mathrm{FeSO}_{4}\right.$ and Sodium nitroprusside, SNP) induced lipid peroxidation in rat's pancreas was assessed. Furthermore, antioxidative properties of the phenolic extracts were evaluated. The result revealed that both leaves extracts inhibit $\mathrm{Fe}^{2+}$ and SNP-induced lipid peroxidation on rat's pancreas in a dose dependent manner $(0-0.5$ $\mathrm{mg} / \mathrm{mL}$ ) and also exhibit antioxidant properties as typified by their $\mathrm{Fe}^{2+}$ chelating, $\mathrm{DPPH}$ and $\mathrm{OH}$ radical scavenging abilities, however, M. macrostachyum leaf had a significantly $(\mathrm{P}<0.05)$ higher $\mathrm{Fe}^{2+}$ and SNP-induced lipid peroxidation on rat's pancreas and antioxidant properties than T. daniellii leaf in vitro. The inhibition of $\mathrm{Fe}^{2+}$ and SNP-induced lipid peroxidation in rat's pancreas by both leaves could be attributed to their reducing power, chelating and radical scavenging abilities. Therefore, this antioxidative potential of both $M$. macrostachyum and $T$. daniellii leaves clearly gives us an insight that they could be used to prevent degenerative disease associated with oxidative stress. Hence, this antioxidant effect could be some possible mechanism by which they are used as food wrappers in order to increase the shelf life of food.
\end{abstract}

\section{INTRODUCTION}

Oxidative stress is as a result of excessive production of free radicals in the body, which react with proteins, cell walls and DNA, causing damage to cell structures that are critical to the immune system (Alia et al., 2003). Free radicals can be defined as molecules or molecular fragments containing one or more unpaired electrons in atomic or molecular orbitals (Halliwell and Gutteridge, 1999), and is produced during normal metabolism in the body cells or due to inflammatory response, stress and environmental pollution. Under normal circumstances, the body maintains equilibrium between pro-oxidants (free radicals) and antioxidants (Oboh and Rocha, 2007). A disturbance in the system's equilibrium; where pro-oxidants outweigh antioxidants

\footnotetext{
* Corresponding Author

Email: ajakinyemi2010@yahoo.co.uk
}

causes the body to lose its ability to neutralize free radicals resulting in oxidative stress (Oboh, 2005), and consequently excessive oxidation in the body cells that can leads to cell death, or higher propensity for disease. Oxidative stress thus is a killer condition. It can be chronic (slow developing) or acute (rapid developing). But sooner or later, result in tissue damage, accelerated aging, degenerative disease, (diabetes mellitus, hypertension, cancer), neurodegenerative diseases, gastric ulcers, reperfusion, arthritis and inflammatory diseases (Vajragupta et al., 2000). However, consumption of foods rich in antioxidants may help fight degenerative diseases caused by oxidative stress by improving body's antioxidant status. In the pancreas, Fe amasses in acinar cells and in the islets of Langerhans, thereby leads to destruction of $\beta$-cells associated with diabetes mellitus (Shah and Fonseca, 2001). High levels of both $\mathrm{Cu}$ and Fe, with low levels of $\mathrm{Zn}$ and Mn play an essential role in the advance of various degenerative diseases (Johnson, 2001). 
Iron is a components of many enzymes and proteins, but high contents of iron in tissues have been associated with several pathological conditions, including cancer (Parkkila et al., 2001), neurodegenerative disorders (Berg et al., 2001), diabetes (Sayre et al., 2000). Fe in the cytosol and mitochondria could cause considerable oxidative damage by acting catalytically in the production of reactive oxygen species (ROS) which have the potential to damage cellular lipids, nucleic acids, proteins and carbohydrate resulting in wide-ranging impairment in cellular function and integrity (Britton et al., 2002).

Sodium nitroprusside (SNP) on the other hand, is a known anti-hypertensive drug; that acts by relaxing vascular smooth muscle and consequently, dilates peripheral arteries and veins. Research has shown that SNP is a potent pro-oxidant capable of causing tissue damage through the release of cyanide and/ or nitric oxide (NO) (Bates et al., 1990), which acts either alone or in conjunction with other reactive oxygen species (ROS), such as superoxide radicals to cause neuronal damage (Halliwell and Gutteridge, 1999). The Fe produced from the decomposition of sodium nitroprusside could sustain the process of lipid peroxidation, by initiating the production of $\mathrm{OH}$ radicals through Fenton's reaction (Oboh et al., 2007). Malondialdehyde (MDA) is the end-product of lipid peroxidation, which is a process where reactive oxygen species (ROS) attack and degrade polyunsaturated fatty acids. This compound is a reactive aldehyde and is one of the many reactive electrophile species that cause toxic stress in cells and form advanced glycation end-products. The production of this aldehyde is used as a biomarker to measure the level of oxidative stress in an organism (Murray et al., 2000).

However, body antioxidant status can be improved by higher consumption of fruits and vegetables. Foods of plant origin are known to contain natural antioxidants such as phenolic compounds that are capable of scavenge free radicals (Oboh and Akindahunsi, 2004). Phenolic compounds are an important group of secondary metabolites, which are synthesized by plants because of plant adaptation to biotic and a biotic stress condition such as infection, water stress, and cold stress (Oboh and Rocha, 2007). Recently, phenolic compounds have drawn the interest of researchers due to their antioxidants capacity; they can protect the human body from free radicals, formed as a result of normal natural metabolism of aerobic cells. The antiradical ability of phenolics is principally based on the structural relationship between different parts of their chemical structure (Rice-Evans et al., 1996). Polyphenols are common constituents of the human diet, present in most foods and beverages of plant origin. They are considered to contribute to the prevention of various degenerative diseases. This assumption originally came from in vitro studies, showing the antioxidant properties of several polyphenols and their ability to modulate the activity of various enzymes. Research suggests that many flavonoids are more potent antioxidant than vitamins C and E (Oboh and Akindahunsi, 2004).

Thaumatococcus daniellii (Benn.) Benth. and Megaphrynium macrostachyum (Benth.) Milne-Redh (Family: Marantaceae) are found in the rainforest of West and Central
Africa (jennings et al., 2001; Arowosoge and Popoola, 2006; Ojekale et al., 2007). The leaves are harvested from the forest and used fresh in wrapping food in order to preserve the food. The leaves are said to give a special taste to the food wrapped in them which is why they are preferred above banana leaves. T. daniellii also known as 'sweet prayers plant or Katempfe', and vernacularly called 'ewe eran' by Yoruba speaking people in south-west Nigeria, bears pale purple flowers and a soft fruit containing one to three black seeds surrounded by a gel and copped with a membranous sac; the aril contains the 'sweet protein' thaumatin (Watson and Dallwitz, 2000). Besides flavoring, the plant has a number of medicinal uses. In vitro activity of $T$. daniellii and $M$. macrostachyum (fondly called 'ngongo' by Baka people of Cameroon (Hattori, 2006) against spoilage fungi of white bread and 'Eba', an indigenous staple food in Southern Nigeria has been reported Grillo and Lawal, 2010), also on the chemical characterization of phyto-constituents and antimicrobial activities of $T$. daniellii and M. macrostachyum, however, there is still limited information on their potential use in the management/ prevention of degenerative diseases associated with oxidative stress. Hence, the objective of this study was to investigate the antioxidant and inhibitory effect of phenolic extracts from $T$. daniellii and M. macrostachyum on some pro-oxidant induced oxidative stress in rat pancreas and heart in vitro.

\section{MATERIALS AND METHODS}

\section{Materials}

Fresh leaves of two species of miracle berry namely; Thaumatococcus daniellii (Benn.) Benth and Megaphrynium macrostachyum (Benth.) Milne-Redh was purchased at the Erekesan market in Akure metropolis, Nigeria. Authentication of the samples was carried out at the Department of Crop Science and Production, Federal University of Technology, Akure, Nigeria. The samples were air-dried and grinded into fine powder. All chemicals and reagents used in this study were of analytical grade and glass-distilled water was used. A JENWAY UV-visible spectrophotometer (Model 6305; Jenway, Barlo world Scientific, Dunmow, United Kingdom) was used to measure absorbance.

\section{Extraction of phenolic extracts}

The extraction of the phenolic extract was carried out according to the method reported by Chu et al., (2002). $10 \mathrm{~g}$ of the fresh leaves was extracted with $100 \mathrm{~mL}$ of $80 \%$ acetone and was filtered (Whatman no. 2) under vacuum. The filtrate was then evaporated using a rotary evaporator under vacuum at $45^{\circ} \mathrm{C}$ until about $90 \%$ of the filtrate had been evaporated. The phenolic extract was frozen and stored for subsequent analysis.

\section{METHODS}

\section{Determination of total phenol content}

The total phenol content was determined according to the method of Singleton et al., (1999). Briefly, appropriate dilutions of the aqueous extracts were oxidized with $2.5 \mathrm{~mL} 10 \%$ Folin- 
Ciocalteau's reagent $(\mathrm{v} / \mathrm{v})$ and neutralized by $2.0 \mathrm{~mL}$ of $7.5 \%$ sodium carbonate. The reaction mixture was incubated for 40 minute at $45^{\circ} \mathrm{C}$ and the absorbance was measured at $765 \mathrm{~nm}$. The total phenol content was subsequently calculated as gallic acid equivalent.

\section{Determination of total flavonoid content}

The total flavonoid content was determined using a slightly modified method reported by Meda et al., (2005), briefly $0.5 \mathrm{~mL}$ of appropriately diluted sample was mixed with $0.5 \mathrm{~mL}$ methanol, $50 \mu \mathrm{L} 10 \% \mathrm{AlCl}_{3}, 50 \mu \mathrm{L} 1 \mathrm{M}$ Potassium acetate and 1.4 $\mathrm{mL}$ water, and allowed to incubate at room temperature for 30 min. The absorbance of the reaction mixture was subsequently measured at $415 \mathrm{~nm}$ and the total flavonoid content was calculated using quercetin as standard.

\section{Lipid peroxidation assay \\ Preparation of Tissue Homogenates}

The rats were decapitated under mild diethyl ether anaesthesia and the tissues (pancreas) was rapidly isolated and placed on ice and weighed. These tissues were subsequently homogenized in cold saline $(1 / 10 \mathrm{w} / \mathrm{v})$ with about 10 -up-and down strokes at approximately $1200 \mathrm{rev} / \mathrm{min}$ in a Teflon glass homogenizer. The homogenates were centrifuged for $10 \mathrm{~min}$ at $3000 x g$ to yield a pellet that were discarded, and a low-speed supernatant (S1) were kept for lipid peroxidation assay (Belle et al., 2004).

\section{Lipid Peroxidation and Thiobarbibutric Acid Reactions}

The lipid peroxidation assay was carried out using the modified method of Ohkawa et al., (1979), briefly $100 \mu \mathrm{L} \mathrm{S1}$ fraction was mixed with a reaction mixture containing $30 \mu \mathrm{L}$ of $0.1 \mathrm{M} \mathrm{pH} 7.4$ Tris- $\mathrm{HCl}$ buffer, extract $(0-100 \mu \mathrm{L})$ and $30 \mu \mathrm{L}$ of $250 \mu \mathrm{M}$ freshly prepared $\mathrm{FeSO}_{4}$ (the procedure was also carried out using $5 \mathrm{mM}$ Sodium nitroprusside). The volume was made up to $300 \mu \mathrm{L}$ by water before incubation at $37^{\circ} \mathrm{C}$ for 1hr.

The color reaction was developed by adding $300 \mu \mathrm{L}$ 8.1\% SDS (Sodium dodecyl sulphate) to the reaction mixture containing $\mathrm{S} 1$, this was subsequently followed by the addition of $500 \mu \mathrm{L}$ of acetic acid/HCl $(\mathrm{pH} 3.4)$ mixture and $500 \mu \mathrm{L} 0.8 \%$ TBA (Thiobarbituric acid). This mixture was incubated at $100^{\circ} \mathrm{C}$ for $1 \mathrm{hr}$. TBARS (Thiobarbituric acid reactive species) produced were measured at $532 \mathrm{~nm}$.

\section{DPPH free radical scavenging ability}

The free radical scavenging ability of the extracts against DPPH (1,1-diphenyl-2 picrylhydrazyl) free radical was evaluated as described by Gyamfi et al., (1999). Briefly, appropriate dilution of the extracts $(1 \mathrm{~mL})$ aliquot was mixed with $1 \mathrm{~mL}, 0.4 \mathrm{mM}$ methanolic solution containing DPPH radicals, the mixture was left in the dark for $30 \mathrm{~min}$ and the absorbance was taken at 516 $\mathrm{nm}$. The DPPH free radical scavenging ability was subsequently calculated.

\section{$\mathrm{Fe}^{2+}$ chelation assay}

The $\mathrm{Fe}^{2+}$ chelating ability of the extracts were determined using a modified method of Minotti and Aust (1987) with a slight modification by Puntel et al., (2005). Freshly prepared $500 \mu \mathrm{M}$ $\mathrm{FeSO}_{4}(150 \mu \mathrm{L})$ was added to a reaction mixture containing 168 $\mu \mathrm{L} 0.1 \mathrm{M}$ Tris- $\mathrm{HCl}(\mathrm{pH} 7.4), 218 \mu \mathrm{L}$ saline and the extracts $(0-$ $25 \mu \mathrm{L})$. The reaction mixture was incubated for $5 \mathrm{~min}$, before the addition of $13 \mu \mathrm{L} \quad 0.25 \% 1$, 10-phenanthroline (w/v). The absorbance was subsequently measured at $510 \mathrm{~nm}$ in the JENWAY UV-visible spectrophotometer. The Fe (II) chelating ability was subsequently calculated.

\section{Fenton reaction (Degradation of Deoxyribose)}

The method of Halliwell and Gutteridge (1981) was used to determine the ability of the extract to prevent $\mathrm{Fe}^{2+} / \mathrm{H}_{2} \mathrm{O}_{2}$ induced decomposition of deoxyribose. The extract $0-100 \mu \mathrm{L}$ was added to a reaction mixture containing $120 \mu \mathrm{L}$ of $20 \mathrm{mM}$ deoxyribose, $400 \mu \mathrm{L}$ of $0.1 \mathrm{M}$ phosphate buffer, $40 \mu \mathrm{L}$ of $500 \mu \mathrm{M}$ of $\mathrm{FeSO}_{4}$, and the volume were made up to $800 \mu \mathrm{L}$ with distilled water. The reaction mixture was incubated at $37^{\circ} \mathrm{C}$ for 30 minutes and the reaction was then stopped by the addition of $0.5 \mathrm{~mL}$ of $2.8 \%$ trichloroacetic acid. This was followed by addition of 0.4 $\mathrm{mL}$ of $0.6 \%$ thiobarbituric acid (TBA) solution. The tubes were subsequently incubated in boiling water for 20 minutes. The absorbance was measured at $532 \mathrm{~nm}$ in the JENWAY UV-visible spectrophotometer. The $\mathrm{OH}^{*}$ scavenging ability was subsequently calculated.

\section{Statistical Analysis}

The results of the three replicates were pooled and expressed as mean \pm standard deviation (STD). Analysis of Variance (ANOVA) and the least significance difference (LSD) were carried out (Zar, 1984). Significance was accepted at P< 0.05 .

\section{RESULTS AND DISCUSSION}

Plants are rich sources of phytochemicals such as polyphenols, and intakes of these plant chemicals have protective potential against degenerative diseases (Chu et al., 2002). Phenolic compounds can protect the human body from free radicals, whose formation is associated with the normal natural metabolism of aerobic cells. The total phenol and flavonoid contents of both phenolic extracts from fresh leaves of Thaumatococcus daniellii and Megaphrynium macrostachyum are presented in Table 1, as gallic acid (GEA) and quercetin (QE) equivalent respectively. The result revealed that $M$. macrostachyum leaf had a significantly $(\mathrm{P}<$ 0.05 ) higher total phenol (49.54 mg GEA/g) than T. daniellii leaf (12.5 mg GEA/g), the result also indicate that M. macrostachyum had significantly $(\mathrm{P}<0.05)$ higher flavonoid content than $(13.24$ $\mathrm{mg} \mathrm{QE} / \mathrm{g}$ ) than $T$. daniellii leaf (10.19 $\mathrm{mg} \mathrm{QE} / \mathrm{g})]$. This finding agrees with many earlier reports where correlations were established between total phenolic and total flavonoid contents (Oboh and Rocha, 2007; Borges de Melo et al., 2006). Phenolics 
are capable of scavenging free radicals, chelate metal catalysts, activate antioxidant enzymes, reduce $\alpha$-tocopherol radicals, and inhibit oxidases (Alia et al., 2003; Amic et al., 2003). Phenolics antioxidant activity is due to the redox properties of their hydroxyl groups (Rice-Evans et al., 1997; Materska and Perucka, 2005). The correlation between total phenol contents and antioxidant activity has been widely studied in different food sources (Klimczak et al., 2007; Oboh et al., 2008) and it has been observed that antioxidant activity of food sources significantly increases with the presence of high concentration of total polyphenolic content (Ghasemi et al., 2009).

Table 1: Total phenols and flavonoid content of fresh leaves of T. daniellii and M. macrostachyum.

\begin{tabular}{lccc}
\hline \multicolumn{1}{c}{ Sample } & $\begin{array}{c}\text { Total phenol } \\
(\mathbf{m g} \text { GEA/g) }\end{array}$ & $\begin{array}{c}\text { Total } \\
\text { flavonoid } \\
(\mathbf{m g} \text { QE/g) }\end{array}$ & $\begin{array}{c}\text { FRAP } \\
(\mathbf{m g ~ A A E} / \mathbf{g})\end{array}$ \\
\hline T. daniellii & $12.50^{\mathrm{b}} \pm 0.7$ & $10.19^{\mathrm{b}} \pm 0.2$ & $54.58^{\mathrm{b}} \pm 8.5$ \\
M. macrostachyum & $49.54^{\mathrm{a}} \pm 1.6$ & $13.25^{\mathrm{a}} \pm 1.5$ & $120.07^{\mathrm{a}} \pm 1.5$ \\
\hline
\end{tabular}

Values represent Mean \pm Standard deviation of triplicate readings. Values with the same superscript along the column are not significantly $(\mathrm{P}<0.05)$ different

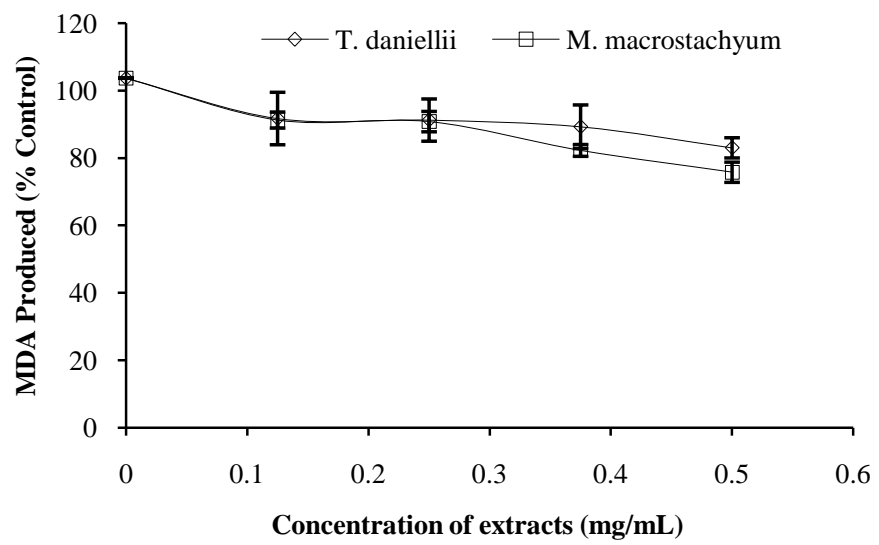

Fig. 1: Inhibition of $\mathrm{Fe}^{2+}$ induced MDA production in rat's pancreas by phenolic extract from M. macrostachyum and T. daniellii leaves.

The lipid peroxidation inhibitory capacity of $T$. daniellii and M. macrostachyum phenolics extracts was carried out in vitro on $\mathrm{FeSO}_{4}$ - induced malondialdehyde (MDA) production in isolated albino rat pancreas homogenate. The result presented in figure 1, agree with our earlier reports on the interaction of $\mathrm{Fe}^{2+}$ with the brain, (Oboh et al., 2012), in which $\mathrm{Fe}^{2+}$ was shown to be a very potent initiator of lipid peroxidation (a pro-oxidant) in the brain.

The increased MDA content in the presence of $250 \mu \mathrm{M}$ $\mathrm{Fe}^{2+}$ could be attributed to the fact that $\mathrm{Fe}^{2+}$ can catalyze oneelectron transfer reactions that generate reactive oxygen species, such as the reactive $\mathrm{OH}^{*}$, which is formed from $\mathrm{H}_{2} \mathrm{O}_{2}$ through the Fenton's reaction. Iron also decomposes lipid peroxides, thus generating peroxyl and alkoxyl radicals, favouring the propagation of lipid oxidation (Zago et al., 2000). However, introduction of the sample extracts caused significant decrease $(p<0.5)$ in the formation of malondialdehyde in a dose dependent manner (0 $0.5 \mathrm{mg} / \mathrm{mL}$ ), with the least MDA production occurring at the introduction of the extracts of $M$. macrostachyum $\left(\mathrm{EC}_{50}=0.96\right.$ $\mathrm{mg} / \mathrm{mL}$ ) (Table 2).

Table 2: $\mathrm{EC}_{50}$ (extract concentration causing 50\% inhibitory effect) value of inhibition of $\mathrm{Fe}^{2+}$ and sodium nitroprusside induced lipid peroxidation in rat pancreas by phenolic extracts from T. daniellii and M. macrostachyum.

\begin{tabular}{lll}
\hline \multicolumn{1}{c}{ Sample } & $\begin{array}{c}\mathbf{F e}^{2+} \text { induced lipid } \\
\text { peroxida } \\
(\mathbf{m g} / \mathbf{m L})\end{array}$ & $\begin{array}{c}\text { SNP induced lipid } \\
\text { peroxidation } \\
(\mathbf{m g} / \mathbf{m L})\end{array}$ \\
\hline T. daniellii & $0.96^{\mathrm{b}} \pm 0.04$ & $10.19^{\mathrm{a}} \pm 0.02$ \\
M. macrostachyum & $1.28^{\mathrm{a}} \pm 0.06$ & $0.74^{\mathrm{b}} \pm 0.04$ \\
\hline
\end{tabular}

Values represent Mean \pm Standard deviation of triplicate readings. Values with the same superscript along the column are not significantly $(\mathrm{P}<0.05)$ different.

Likewise, incubation of rat's pancreas tissue homogenates in the presence of SNP also caused a significant $(\mathrm{P}<$ 0.05 ) increase in the rat pancreas MDA content, as shown in Figure 2; however, both extracts inhibited MDA content in both tissues in a dose-dependent manner $(0-0.5 \mathrm{mg} / \mathrm{mL})$. Phenolic extract of $M$. macrostachyum $\left(\mathrm{EC}_{50}=0.68 \mathrm{mg} / \mathrm{mL}\right)$ was found to have higher inhibitory effect on MDA production in the rat pancreas in vitro than did $T$. daniellii $\left(\mathrm{EC}_{50}=0.74 \mathrm{mg} / \mathrm{mL}\right)$ according to Table 2. SNP; a component of antihypertensive drugs, causes cytotoxicity through the release of cyanide and nitric oxide (NO) (Oboh and Rocha, 2008).

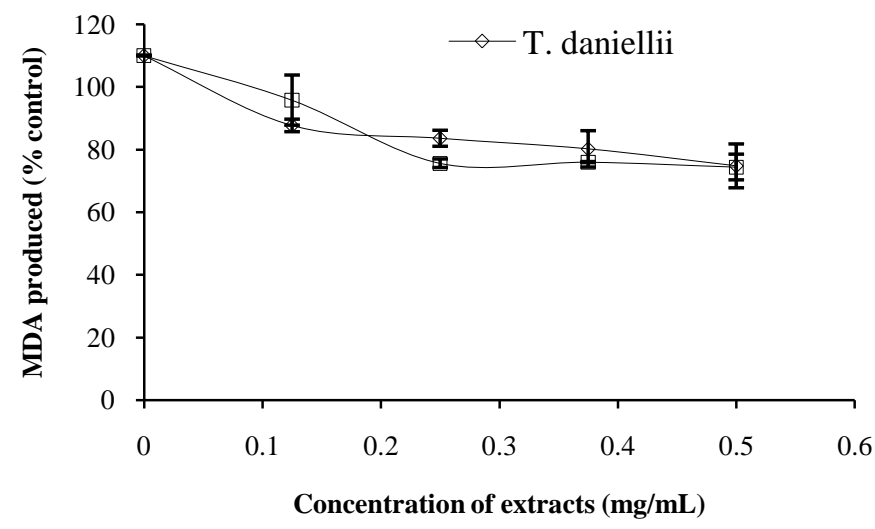

Fig. 2: Inhibition of sodium nitroprusside induced MDA in rat's pancreas by phenolic extract of $M$. macrostachyum and $T$. daniellii leaves.

The protective properties of the $T$. daniellii and $M$. macrostachyum against SNP-induced lipid peroxidation in the heart could be because of the ability of the antioxidant phytochemicals present in the extract to scavenge the nitrous and Fe radicals produced from the decomposition of SNP. Inhibition of MDA production is one of the indices of antioxidant properties (Oboh et al., 2007). The inhibition can be attributed to the formation of complexes by the phenolic constituents of the extracts with $\mathrm{Fe}^{2+}$, thus preventing the catalysis of the initiation stage of lipid peroxidation (Oboh et al., 2007). Neutralizing/ scavenging, prevention of produced free radicals in the body or by reducing/chelating the transition metal composition of foods (Alia et al., 2003; Amic et al., 2003) is the major ways in which antioxidants agent protect cells. To explain the mechanisms through which the phenolic extracts protect pancreas tissue against 
$\mathrm{Fe}^{2+}$ and SNP - induced lipid peroxidation, the DPPH radical scavenging and $\mathrm{Fe}^{2+}$-chelating abilities were assessed. The prevention of the chain initiation step by scavenging various reactive species such as free radicals is considered to be an important antioxidant mode of action (Dastmalchi et al., 2007).

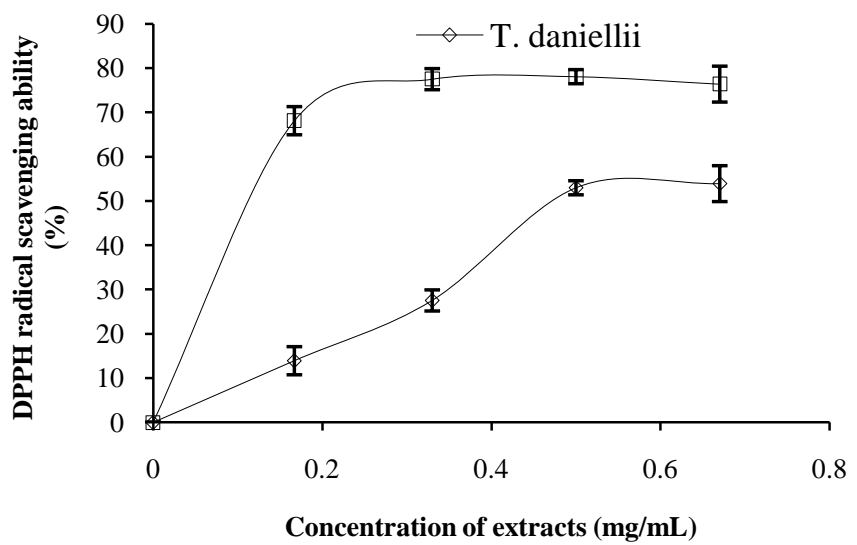

Fig. 3: DPPH free radical scavenging ability of the phenolic extracts from $M$. macrostachyum and T. daniellii leaves.

DPPH is a free radical donor that accepts an electron or hydrogen to become a stable diamagnetic molecule (Je et al., 2009). The tendencies of electron or hydrogen donation are critical factors in characterizing antioxidant activity that involves free radical scavenging (Hu et al., 2000). Foods of plant origin usually contain natural antioxidants that can scavenge free radicals (Osawa et al., 1995). These antioxidants are polyphenolic compounds which have protective effect against diseases (Osawa et al., 1995) and can be found in all plants and in all parts of the plants (Osawa et al., 1995). The DPPH radical scavenging ability of the extract from M. macrostachyum and T. daniellii represented in Figure 3 revealed that both phenolic extracts scavenged $\mathrm{DPPH}^{*}$ in a dose dependent manner $(0-0.67 \mathrm{mg} / \mathrm{mL})$, however, judging by the $\mathrm{EC}_{50}$ value (Table 3), the phenolic extract of M. macrostachyum leaf $\left(\mathrm{EC}_{50}=0.33 \mathrm{mg} / \mathrm{mL}\right)$ had a significantly $(\mathrm{P}<0.05)$ higher $\mathrm{DPPH}^{*}$ scavenging ability than that of $T$. daniellii leaf $\left(\mathrm{EC}_{50}=\right.$ $0.56 \mathrm{mg} / \mathrm{mL}$ ).

Table 3: $\mathrm{EC}_{50}$ (extract concentration causing 50\% scavenging and chelating ability) value of $\mathrm{DPPH}^{*}, \mathrm{OH}^{*}$ scavenging and $\mathrm{Fe}^{2+}$ chelating ability of phenolic extracts from $T$. daniellii and M. macrostachyum $(\mathrm{mg} / \mathrm{mL})$.

\begin{tabular}{llll}
\hline Sample & DPPH* & Fe $^{2+}$ & $\mathbf{O H}^{*}$ \\
\hline T. daniellii & $0.56^{\mathrm{a}} \pm 0.07$ & $4.01^{\mathrm{a}} \pm 0.05$ & $0.76^{\mathrm{a}} \pm 0.2$ \\
M. macrostachyum & $0.33^{\mathrm{b}} \pm 0.05$ & $2.49^{\mathrm{b}} \pm 0.03$ & $0.79^{\mathrm{a}} \pm 0.4$ \\
\hline
\end{tabular}

Values represent Mean \pm Standard deviation of triplicate readings. Values with the same superscript along the column are not significantly $(\mathrm{P}<0.05)$ different

More so, the $\mathrm{Fe}^{2+}$ chelating ability (Figure 4) in dose dependent manner $(0-0.08 \mathrm{mg} / \mathrm{mL})$ of the phenolic extract agree with the $\mathrm{Fe}^{2+}$-induced lipid peroxidation (Figure 1) result, total phenolic content (Table 1), however, the phenolic extract of $M$. macrostachyum leaf $\left(\mathrm{EC}_{50}=2.49 \mathrm{mg} / \mathrm{mL}\right)$ had a significantly higher $(\mathrm{P}<0.05) \mathrm{Fe}^{2+}$ chelating ability than that of $T$. daniellii leaf $\left(\mathrm{EC}_{50}=4.01 \mathrm{mg} / \mathrm{mL}\right)$. Fe chelation may be one of the possible mechanisms through which antioxidant phytochemicals $M$. macrostachyum and T. daniellii prevent lipid peroxidation in tissue by forming a complex with $\mathrm{Fe}$, thus preventing the initiation of lipid peroxidation.

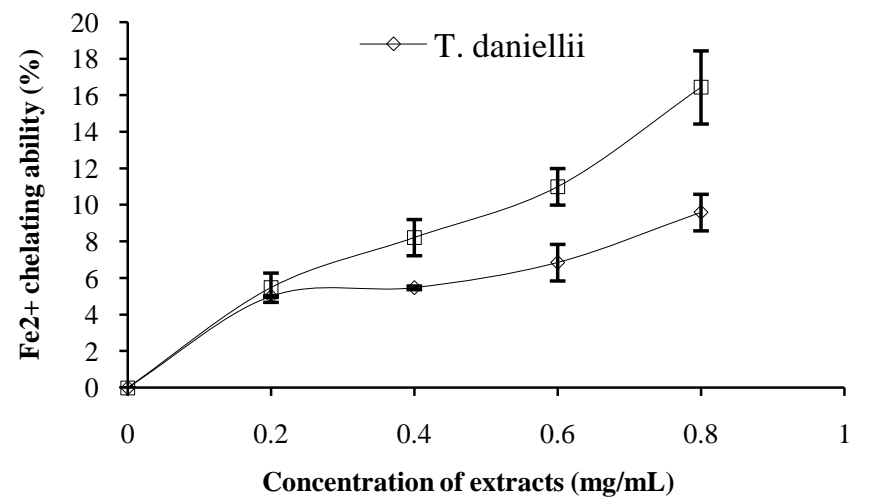

Figure 4: $\mathrm{Fe}^{2+}$ chelating ability of the phenolic extracts from $M$. macrostachyum and T. daniellii leaves.

Like the $\mathrm{Fe}^{2+}$ chelating ability, the $\mathrm{OH}^{*}$ scavenging ability of the M. macrostachyum and T. daniellii extracts agreed with the extractable phytochemicals (Table 1). The hydroxyl radical $\left(\mathrm{OH}^{*}\right)$ scavenging ability of the extracts of $M$. macrostachyum and T. daniellii leaves are presented in Figure 5. The results revealed that both extracts were able to scavenge $\mathrm{OH}^{*}$ produced from the decomposition of deoxyribose in Fenton reaction in a dose-dependent manner $(0-0.571 \mathrm{mg} / \mathrm{mL})$. This clearly showed that part of the mechanisms through which the phenolic extracts from both leaves protect the pancreas may be through their $\mathrm{Fe}^{2+}$ chelating and $\mathrm{OH}^{*}$ scavenging ability. However, according to the $\mathrm{EC}_{50}$ (Table 3), there was no significant $(\mathrm{P}>0.05)$ difference in the $\mathrm{OH}^{*}$ scavenging ability between the extract of $M$. macrostachyum leaf $\left(\mathrm{EC}_{50}=0.76 \mathrm{mg} / \mathrm{mL}\right)$ and $T$. daniellii leaf $\left(\mathrm{EC}_{50}=0.76 \mathrm{mg} / \mathrm{mL}\right)$.

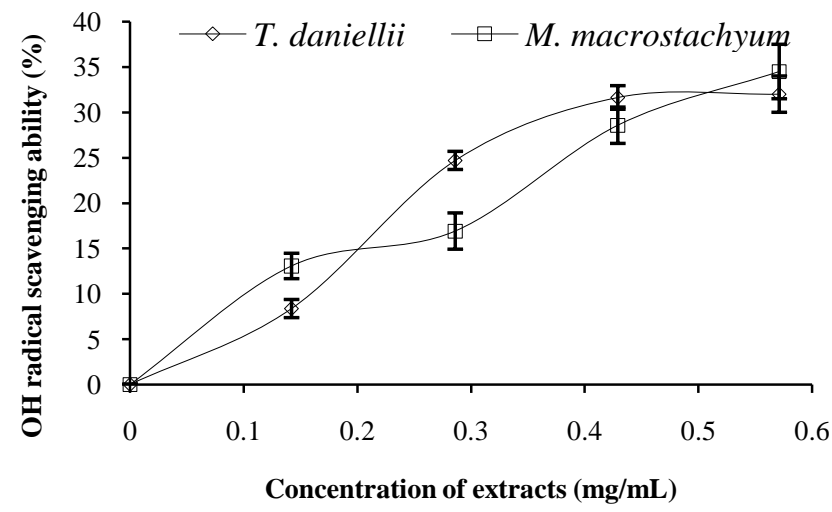

Fig. 5: $\mathrm{OH}$ radical scavenging ability of the phenolic extracts from $M$. macrostachyum and T. daniellii leaves.

Furthermore, the reducing power of the extractable phenols from M. macrostachyum and $T$. daniellii expressed as ascorbic acid equivalent (AAE) were presented in Table 1. The reducing power as typified by the ability of the plant extracts to 
reduce $\mathrm{Fe}^{3+}$ to $\mathrm{Fe}^{2+}$ is a potent antioxidation defense mechanism, and two mechanisms available to affect this reducing power is by electron transfer and hydrogen atom transfer (Oboh, 2008). According to Allhorn et al., (2005) who reported that the reducing property can be a novel anti-oxidation defense mechanism, possibly through the ability of the antioxidant compound to reduce transition metals. Therefore, the higher reducing ability of $M$. macrostachyum (120.07 mg AAE/g) extract may have contributed to its higher protective effect observed than T. daniellii $(54.58 \mathrm{mg}$ $\mathrm{AAE} / \mathrm{g})$.

\section{CONCLUSION}

The phenolic extract of the leaves of M. macrostachyum and $T$. daniellii were able to protect the pancreas and tissues from $\mathrm{Fe}^{2+}$ and SNP induced lipid peroxidation in vitro. And part of the mechanisms through which the phenolic extracts from the leaves of M. macrostachyum and T. daniellii protect the pancreas may be through their Fe (II) chelating ability, radical scavenging abilities and reducing power. However, the phenolic extract of $M$. macrostachyum leaf had a higher protective effect against $\mathrm{Fe}^{2+}$ and SNP induced lipid peroxidation in pancreas than that of T. daniellii leaf in vitro.

\section{REFERENCES}

Alia M, Horcajo C, Bravo L, Goya L. Effect of grape antioxidant dietary fibre on the total antioxidant capacity and the activity of liver antioxidant enzymes in rats. Nutr Res, 2003; 23:1251-1267.

Allhorn M, Klapyta A, Åkerström B. Redox properties of the lipocalin $\alpha 1$-microglobulin: reduction of cytochrome c, hemoglobin, and free iron. Free Rad Biol Med, 2005; 38:557-567.

Amic D, Davidovic-Amic D, Beslo D, Trinajstic N. Structureradical scavenging activity relationship of flavonoids. Croat Chem Acta, 2003; 76:55-61.

Arowosoge OGE, Popoola L. Economic analysis of Thaumatococcus danielli (Benn.) Benth. (Miraculous berry) in Ekiti State, Nigeria. J Food Agric Environ, 2006; 4:264-269.

Bates JN, Baker MT, Guerra R, Harrison DG. Nitric oxide generation from nitroprusside by vascular tissue. Biochem Pharmacol, 1990; 42:S157-S165.

Belle NAV, Dalmolin GD, Fonini G, Rubim MA, Rocha JBT. Polyamines reduces lipid peroxidation induced by different pro-oxidant agents. Brain Res, 2004; 1008:245-251.

Berg D, Gerlach M, Youdim MB, Double KL, Zecca L, Riederer P, Becker G. Brain iron pathways and their relevance to Parkinson's disease. J Neurochem, 2001; 79:225-236.

Borges de Melo E, Adriane da Silveira G, Ivone C. $\alpha$-and $\alpha$ Glucosidase inhibitors: chemical structure and biological activity. J Tetrahed, 2006; 62:10277-10302.

Britton RS, Leicester KL, Bacon BR. Iron toxicity and chelation therapy. Int'1 J Hematol, 2002; 76:219-228.

Chu Y, Sun J, Wu X, Liu RH. Antioxidant and antiproliferative activity of common vegetables. J Agric Food Chem, 2002: 50:6910-6916.

Dastmalchi K, Damien DHJ, Kosar MM, Hiltunen R. Chemical composition and in vitro antioxidant evaluation of a water-soluble Moldavian balm (Dracocephalum moldavica L.) extract. LWT-Food Sci Technol, 2007; 40:239-248.

Ghasemi K, Ghasemi Y, Brahimzadeh MA. Antioxidant Activity, Phenol and Flavonoid Contents of 13 Citrus species peels and tissues. Pak J Pharm Sci, 2009; 22:277-28.

Grillo JA, Lawal AK. In vitro activity of Thaumatococcus daniellii and Megaphrynium macrostachyum against spoilage fungi of white bread and 'Eba' an indigenous staple food in Southern Nigeria. Afr J Microbiol Res, 2010; 4:1076-1081.

Gyamfi MA, Yonamine M, Aniya Y. Free-radical scavenging action of medicinal herbs from Ghana: Thonningia sanguinea on experimentally-induced liver injuries. Gen Pharmacol, 1999; 32:661-667.

Halliwell B, Gutterdge JMC. Formation of a thiobarbituric-acidreactive substance from deoxyribose in the presence of iron salts: The role of superoxide and hydroxyl radicals. FEBS lett, 1981; 128:347352.

Halliwell B, Gutteridge JMC. Free radicals in biology and medicine (3rd ed.). Oxford University Press, 1999.

Hattori, S. Utilization of marantaceae plants by the baka huntergatherers in southeastern Cameroon. Afri study monographs, 2006; 33:2948

Hu C, Zhang Y, Kitts DD. Evaluation of antioxidant and prooxidant activities of bamboo Phyllostachys nigra var. Henonis leaf extract in vitro. J Agric Food Chem, 2000; 48:3170-3176.

Je JY, Park PJ, Kim EK, Ahn CB. Antioxidant and angiotensin I converting enzyme inhibitory activity of Bambusae caulis in Liquamen. Food Chem, 2009; 113:932-935.

Jennings SB, Brown ND, Boshier DH, Whitmore TC, Lopes JA Ecology provides a pragmatic solution to the maintenance of genetic diversity in sustainably managed tropical rainforest. For Ecol Manage, 2001; 154:1-10.

Johnson S. The possible crucial role of iron accumulation combined with low tryptophan zinc and manganese in carcinogenesis. Medical Hyp, 2001; 57:539-543.

Klimczak I, Malecka M, Szlachta M, Gliszczynska-Swiglo A. Effect of storage on the content of polyphenols, vitamin $\mathrm{C}$ and the antioxidant activity of orange juices. JFood Comp Anal, 2007; 20:313322.

Materska M, Perucka I. Antioxidant activity of the main phenolic compounds isolated from hot pepper fruits (Capsicum annuum L.). J Agric Food Chem, 2005; 53:1730-1758.

Meda A, Lamien CE, Romito M, Millogo J, Nacoulma OG. Determination of the total phenolic, flavonoid and proline contents in Burkina Faso honey, as well as their radical scavenging activity. Food Chem, 2005; 91:571-577.

Minotti G, Aust SD. An investigation into the mechanism of citrate- $\mathrm{Fe}^{2+}$ - dependent lipid peroxidation. Free Rad Biol Med, 1987; 3:379-387.

Murray RK, Granner DK, Mayes PA, Rodwell VW. Harper's Biochemistry. $25^{\text {th }}$ Edition 2000; 133-134, 640-649,766-776, 873-885.

Oboh G. Polyphenol extracts from Hyptis suaveolens leaves inhibit $\mathrm{Fe}^{2+}$-induced lipid peroxidation in brain. Int'l J Biomed Pharma Sci, 2008; 2:41-46.

Oboh G. Effect of blanching on the antioxidant property of some tropical green leafy vegetables. Lebensm Wissens Technolog, 2005; 38:513-517.

Oboh G, Akinyemi AJ, Ademiluyi AO. Antioxidant and inhibitory effect of red ginger (Zingiber officinale var. Rubra) and white ginger (Zingiber officinale var Roscoe) on $\mathrm{Fe}^{2+}$ - induced lipid peroxidation in rat brain in vitro. Exp Toxicol Pathol, 2012; 64:31-36.

Oboh G, Akindahunsi AA. Change in the ascorbic acid, total phenol and antioxidant activity of some sun-dried green leafy vegetables in Nigeria. Nutr Health, 2004; 18:29-36.

Oboh G, Puntel RL, Rocha JBT. Hot pepper (Capsicum annuum, Tepin and Capsicum chinese, Habanero) prevents $\mathrm{Fe}^{2+}$ - induced lipid peroxidation in Brain - in vitro. Food Chem, 2007; 102:178-185.

Oboh G, Raddatz H, Henle T. Antioxidant properties of polar and non-polar extracts of some tropical green leafy vegetables. J Sci Food Agric, 2008; 88:2486-2492.

Oboh G, Rocha JBT. Antioxidant and neuroprotective properties of sour tea (Hibiscus sabdariffa, calyx) and green tea (Camellia sinensis) on some pro-oxidants induced lipid peroxidation in brain-in vitro. Food Biophys, 2008; 3:382-389.

Oboh G, Rocha JBT. Polyphenols in red pepper [Capsicum annuиm var. aviculare Tepin] and their protective effect on some pro- 
oxidants induced lipid peroxidation in brain and liver. Eur Food Res Technol, 2007; 225:239-247.

Ojekale AB, Makinde SCO, Osileye O. Phytochemistry and anti-microbial evaluation of Thaumatococcus danielli, Benn. (Benth.) leaves. Nigerian Food J, 2007; 25:176-183.

Okhawa H, Ohishi N, Yagi K. Assay for lipid peroxides in animal tissues by thiobarbituric acid reaction. Anal Biochem, 1979; 95:351-358.

Osawa T, Yoshida S, Yamashida K, Ochi H. 1995. Protective role of dietary antioxidants in oxidative stress. in Oxidative Stress and Aging, Cutler RG, Packer L, Bertram J, Mori A, Ed., Birkhauser, Basel, Switzerland. pp. 367-377.

Parkkila S, Niemela O, Savolainen ER, Koistinen P. HFE mutations do not account for transfusional iron overload in patients with acute myeloid leukemia. Transfusion, 2001; 41:828-831.

Puntel RL, Nogueira CW, Rocha JBT. Krebs cycle intermediates modulate thiobarbituric reactive species (TBARS) production in Rat Brain In vitro. Neurochem Res, 2005; 30:225-235.

Rice-Evans CA, Miller NJ, Paganga G. Structure-antioxidant activity relationships of flavonoids and phenolic acids. Free Rad Biol Med, 1996; 20:993-956.

Rice-Evans CA, Miller NJ, Paganga G. Antioxidant properties of phenolic compounds. Trends Plant Sci, 1997; 2:152-159.

Sayre LM, Perry G, Atwood CS, Smith MA. The role of metals in neurodegenerative diseases. Cell Mol Biol, 2000; 46:731-741.
Shah SV, Fonseca VA. Iron and Diabetes Revisited. Diabetes Care, 2004; 34:1676-1677.

Singleton VL, Orthofor R, Lamuela-Raventos RM. Analysis of total phenols and other oxidation substrates and antioxidants by means of Folin-Ciocaltau reagent. Met Enzymol, 1999; 299:152-178.

Vajragupta O, Boonchoong P, Wongkrajang Y. Comparative quantitative structure-activity study or radical scavengers. Bioorg Med Chem, 2000; 8:2617-2628.

Watson L, Dallwitz MJ. The Families of Flowering Plants: descriptions, Illustrations, Identification, and Information Retrieval. Version. 27th Sept. 2000; http://biodiversity.uno.edu/delta.

Zago MP, Verstraeten SV, Oteiza PI. Zinc in the prevention of $\mathrm{Fe}^{2+}$-initiated lipid and protein oxidation. Biol Res, 2000; 33:143-150.

Zar JH. Biostatistical analysis. USA: Prentice-Hall Inc. 1984; 620.

\section{How to cite this article:}

Ganiyu Oboh, Ayodele J Akinyemi, kemi Williamnelson, Idowu S Oyeleye. Protective effect of phenolic extracts from two species of miracle berry leaves (Thaumatococcus daniellii and Megaphrynium macrostachyum) on some pro-oxidant induced oxidative stress in rat pancreas in vitro. J App Pharm Sci, 2016; 6 (01): 118-124. 